\title{
Rediscovering hermaphroditism in Grammatidae with the description of the testicular gland in Brazilian Basslet Gramma brasiliensis
}

\author{
J. R. Leite ${ }^{a *}$, M. O. Freitas ${ }^{b}$, E. G. Sanches ${ }^{c}$, M. L. M. Gomes ${ }^{d}$, \\ M. Hostim-Silva and K. S. Cole
}

${ }^{a}$ Laboratório de Vertebrados Aquáticos, Pós-graduação em Oceanografia Ambiental, Departamento de Ciências Agrárias e Biológicas - DCAB, Centro Universitário Norte do Espírito Santo - CEUNES, Universidade Federal do Espírito Santo - UFES, Rodovia BR 101 Norte, Km 60, Litorâneo, s/n, CEP 29932-540, São Mateus, ES, Brazil

${ }^{\text {b} G r u p o ~ d e ~ P e s q u i s a ~ e m ~ I c t i o f a u n a, ~ L a b o r a t o ́ r i o ~ d e ~ I c t i o l o g i a, ~ M u s e u ~ d e ~ H i s t o ́ r i a ~ N a t u r a l ~ C a p a ̃ o ~ d a ~ I m b u i a, ~}$ Rua Prof. Benedito Conceição, 407, Capão da Imbuia, CEP 82810-080, Curitiba, PR, Brazil

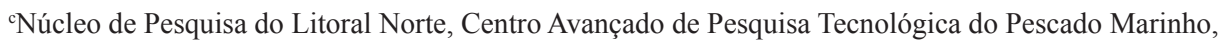
Instituto de Pesca de São Paulo - IPSP, Avenida Cais do Porto, 2275, Itaguá, CEP 11680-000, Ubatuba, SP, Brazil

${ }^{d}$ Laboratório de Biologia Estrutural e Reprodução - LABER, Departamento de Morfologia, Instituto de Ciências Biológicas, Universidade Federal de Minas Gerais - UFMG, bloco O3, sala 165, Av. Antônio Carlos, 6627, Pampulha, CEP 31270-901, Belo Horizonte, MG, Brazil

eDepartment of Biology, University of Hawai'i at Manoa, Room EDM 416, 2538 McCarthy Mall, Edmondson Hall 216, Honolulu, HI 96822, USA

*e-mail: jonasipaq@yahoo.com.br

Received: February 25, 2015 - Accepted: June 10, 2015 - Distributed: August 31, 2016 (With 3 figures)

\begin{abstract}
Many aspects of sex change in reef fishes have been studied, including behavior and social organization. However, gonad histology remains the most robust way to identify sexual patterns in fishes. Some uncommon tissues remain poorly described, such as the accessory gonadal structures found in species from the Gobiidae family, which are rare in other bony fishes. This is the first report of the testicular gland in Gramma brasiliensis and for the Grammatidae family. Between April 2011 and February 2012 eighty specimens were collected during four dive campaigns on the

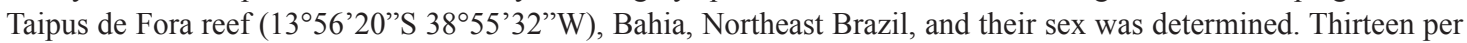
cent of the active-females and $90 \%$ of the active-males had testicular gland tissue in their ovotestis. This discovery led to additional research into the characteristics of the gland tissue and its relationship with gonadal maturation. Three patterns of testicular gland development were found in Brazilian basslet ovotestis. Both ova and sperm-producing gonad contained testicular gland tissue, and the appearance of this tissue seems to be the first modification of ovotestis tissue marking the beginning of the protogynous sex-change process in G. brasiliensis.
\end{abstract}

Keywords: accessory gonoduct structure, sex change, hermaphroditism, reef fish.

\section{Redescobrindo o hermafroditismo em Grammatidae com a descrição da glândula testicular de Gramma brasiliensis}

\section{Resumo}

Diversos aspectos da troca de sexo em peixes recifais vem sendo estudados, incluindo comportamentos e organização social. Entretanto, a histologia das gônadas continua sendo a maneira mais robusta para se identificar padrões sexuais em peixes. Alguns tecidos incomuns, tais como as estruturas anexas a gônada encontradas em espécies da família Gobiidae e raras em outras espécies são pouco estudados. Este trabalho é a primeira descrição da glândula testicular em Gramma brasiliensis e para a família Grammatidae. Entre abril de 2011 e fevereiro de 2012, oitenta espécimes foram coletados durante quatro amostragens no recife de Taipus de Fora (135'20"S 38 55'32"W), Bahia, Brasil, e tiveram seus sexos determinados. Treze por cento das fêmeas ativas e noventa por cento dos machos ativos apresentaram tecido da glândula testicular em suas gônadas. Esta descoberta levou ao estudo da características dessa estrutura e sua relação com a maturação gonadal. Foram identificados três padrões de desenvolvimento da glândula testicular nas gônadas do Gramma brasiliensis. Tanto as gônadas produtoras de espermatozoides quanto as de oócitos apresentaram tecido da glândula testicular, e o surgimento desse tecido parece ser a primeira modificação gonadal do início da troca de sexo protogínica em G. brasiliensis.

Palavras-chave: estrutura anexa ao gonoduto, troca de sexo, hermafroditismo, peixe recifal. 


\section{Introduction}

The teleost family Grammatidae is composed of thirteen species: eight in the genus Lipogramma and five in the genus Gramma (Böhlke and Randall, 1963; Starck II and Colin, 1978; Sazima et al., 1998; Victor and Randall, 2010), all of which are restricted to the western Atlantic (Gill and Mooi, 1993). Lipogramma species inhabit manly deep reefs, from 30 to more than $300 \mathrm{~m}$ (Gilmore, 1997) and have not been well studied. In contrast, Gramma species occur in shallow reefs (from 0 to $100 \mathrm{~m}$ ) but only the biology of the Fairy Basslet, Gramma loreto Poey 1868 , has been studied to any extent (Asoh and Shapiro, 1997; Gutiérrez and Báez-Hidalgo, 2002). In Brazilian coastal waters, only one species occurs, the endemic Brazilian Basslet, Gramma brasiliensis Sazima, Gasparini and Moura 1998 (Sazima et al., 1998).

The Brazilian Basslet occurs in coastal waters from Maranhão State $\left(01^{\circ} 01^{\prime} \mathrm{S} 41^{\circ} 48^{\prime} \mathrm{W}\right)$ to the north of Rio de Janeiro state $\left(22^{\circ} 54>\mathrm{S} 41^{\circ} 59^{\prime} \mathrm{W}\right)$, including the Fernando de Noronha archipelago (03⒌ $51^{\prime} \mathrm{S} 32^{\circ} 25^{\prime} \mathrm{W}$ ) and Manuel Luiz reefs $\left(00^{\circ} 51^{\prime} \mathrm{S} 44^{\circ} 15^{\prime} \mathrm{W}\right)$. Individuals have a vibrant purple and yellow colouration, and have become increasingly exploited by the ornamental trade (Monteiro-Neto et al., 2003; Gasparini et al., 2005). This, combined with loss of habitat due to degradation of coastal waters, has led the species to be classified as endangered (Brasil, 2004; Sampaio and Notthingham, 2007). The only two scientific studies of $G$. brasiliensis include the species description (Sazima et al., 1998), and a recent genetic study hypothesizing the speciation of the sister-species, suggesting that Brazilian Basslet derived from $G$. loreto by biogeographic isolation across the Amazon/Orinoco barrier (Molina et al., 2012). Accordingly, G. brasiliensis is included in a list of Brazilian reef fish species with Caribbean kinship (Floeter et al., 2008).

In the absence of biological information for $G$. brasiliensis, the biology known for $G$. loreto has been considered applicable to G. brasiliensis. Thus, G. brasiliensis has been assumed, like G. loreto, to exhibit gonochorism (De Mitcheson and Liu, 2008) and nest-building behaviour with demersal spawning and male parental care (Asoh and Shapiro 1997; Sazima et al., 1998).

Asoh and Shapiro (1997) studied the sexual pattern of G. loreto and in a histological analysis they described a medial region of the gonads containing an anastomosing network of sperm ducts lined with cuboidal cells that merged into a lateral region containing germinal tissue. These tissue characteristics were similar to those found in the accessory gonadal/gonoduct structures of some Blenniidae (Lahnsteiner et al., 1993; Richtarski and Patzner, 2000). A similar type of tissue has also been described for some goby (Family Gobiidae) species, which may occur in the gonad proper as a 'mesorchial gland' (Colombo and Burighel, 1974; Colombo et al., 1977) or may be located in accessory structure(s) previously referred to as seminal vesicles (Eggert, 1931; Young and Fox, 1937) or sperm duct glands (Miller, 1984) and more recently as accessory gonadal structures, or AGS (Cole and Robertson, 1988) (see Fishelson, 1991 for summary). In protogynous goby species in which individuals shift unidirectionally from ova to sperm production, the AGS that develop during sexual transition arise from precursive accessory gonadal structures (pAGS) associated with the ovary (Cole, 1988). In these species there is no specialized gland-like tissue embedded within the testis proper and it is unclear to what extent gobiid AGS may provide a similar function to the tissues described by Asoh and Shapiro (1997) for G. loreto (Cole, pers comm.). Hermaphroditic fish species can differ markedly in terms of testicular and ovarian tissue configuration before, during and following sex change (Cole, 1990). The presence of AGS diversifies even more these gonadal patterns. According to De Mitcheson and Liu (2008), new studies are revealing the functions and importance of the testicular gland for demersal spawning species. Among gobiid species, the presence and spatial arrangement of differing gametogenic tissues within the gonad proper and the configuration of gonad-associated pAGS and/or AGS can vary considerably (Cole, 2010).

In Asoh and Shapiro's (1997) study, the authors examined $G$. loreto for indications of a hermaphroditic sexual pattern. A previous report had described both ovarian and testicular features in the immature gonad and a diagnosis of protogynous hermaphroditism (Corsten-Hulsmans and Corsten, 1974). The retention of ovarian features in the testis and/or typical testis features within the ovary can indicate a functional hermaphroditic sexual pattern (De Mitcheson and Liu, 2008). In Asoh and Shapiro's (1997) subsequent study of G. loreto, however, they concluded that there was no support for functional hermaphroditism and assigned a gonochoric sexual pattern. The goal of this study was to examine reproductive morphology of G. brasiliensis to determine if: (i) the gonad structure is similar to that found in G. loreto; and (ii) the gonadal histostructure of G. brasiliensis indicates a hermaphroditic sexual pattern. This is the first study on reproductive biology for this species, and these data will form the basis for hypotheses of sexual patterns for this species along the Brazilian coast.

\section{Material and Methods}

Sampling was carried out seasonally between April 2011 and February 2012 on the Taipus de Fora reef (13 $56^{\circ} 20^{\prime \prime} S$ 3855'32”W), Bahia, Northeast Brazil. Gramma brasiliensis were captured with hand nets (SISBIO authorization number 22123-1, authentication code 45533572 - 16/02/2011) during SCUBA dives. Fish were anaesthetised with eugenol $\left(50 \mathrm{mg} / \mathrm{L}^{-1}\right)$ and fixed in formalin $(10 \%)$; after 48 hours, samples were transferred to ethyl alcohol (70\%).

A total of 80 fish were collected. The biometric data taken included total length $(\mathrm{mm})$ and total weight $(\mathrm{g})$. Gonads were subsequently removed to determine sex and gonadal maturation stage. First, the entire gonad was examined using a stereomicroscope, then dehydrated in an increasing ethyl alcohol concentration series, cleared in xylene and embedded in histological paraffin (Beçak and 
Paulete, 1976). Transverse and longitudinal histological sections $(\cong 5 \mu \mathrm{m})$ were generated using a microtome, then stained with Harris hematoxylin and eosin.

For sex determination, the presence and developmental phase of sex cells were classified according to the criteria of Brown-Peterson et al., (2011), in five phases, immature (never spawned), developing (ovaries or testis beginning to develop, but not ready to spawn), spawning capable I and II (fish are developmentally and physiologically able to spawn in this cycle), regressing (cessation of spawning) and regenerating (sexually mature, reproductively inactive).

Tissues in the G. brasiliensis gonad complex were identified based on the characteristics described by Miller (1992) in male Gobiidae as a testicular gland and by Asoh and Shapiro (1997) for G. loreto. Here we refer to this morphological feature as the testicular gland (TG).

\section{Results}

Gonad histological examination revealed that $47.5 \%$ of the fish had an ovariform gonad $(n=38)$ and that $52.5 \%$ had a testiform gonad $(n=42)$. For individuals having an ovariform and testiform gonad, respectively, total length and weight ranged from $31 \mathrm{~mm} 0.3 \mathrm{~g}$ to $84 \mathrm{~mm} 10.40 \mathrm{~g}$, and $44 \mathrm{~mm} 1.19 \mathrm{~g}$ to $96 \mathrm{~mm} 16 \mathrm{~g}$ (statistically different Mann- Whitney U-test, $\mathrm{P}<0.05)$. Sexual differentiation was not evident by gross examination (i.e., no macroscopic differences between germinal tissue and TG tissue were visible).

The reproductive system of G. brasiliensis consisted of two gonadal lobes, with a medial duct/lumen in each lobe. These structures were united posteriorly to form a single duct connected to the urogenital papilla.
Microscopic analyses confirmed the presence of testicular gland tissue in the G. brasiliensis gonad complex. Cuboidal cells present in the testicular gland (TG) had a spherical apically nucleus and cytoplasm with numerous vacuoles (Figure 1). In males, these cells made up much of the walls of tubules that formed an anastomosing network emptying into one of several large ducts. The tubule network made up a large portion of testiform gonad complex. Transition tissue, characterised by tubules having thinner walls and broader tubule lumina relative to TG tissue, was located between the TG and spermatogenic tissue regions of the gonad (Figure 2). The presence of spermatogonia and spermatozoa in these lumina indicated that these tubules were connected to one or more medial ducts that also contained spermatozoa. The TG region was directly confluent with the seminiferous lobules of the spermatogenic region of the gonad such that spermatozoa have to pass through the TG tubules in order to enter the spermatic duct.

From the $80 \mathrm{G}$. brasiliensis analysed, $90 \%$ of the "male-active" $(\mathrm{N}=42)$ and $13 \%$ of the "female-active" $(\mathrm{N}=38)$ had TG tissue associated with the gonad (Table 1).

Three patterns of TG tissue position and quantity were identified. In individuals having a gonad predominated by oogenic tissue and various developmental stages of oocytes, a small region appearing identical to inactive (non-secreting) TG tissue was present in the caudal region of the gonad closest to the gonoduct. Among reproductively inactive individuals within the above group, only primary growth (PG) oocytes were present. Among reproductively active fish, oocytes in various stages of development including vitellogenic oocytes were present while the gonad of post-spawning fish were characterized by the presence of yellow-brown bodies and large, centrally located gonadal lumen (Figure 3a, b).

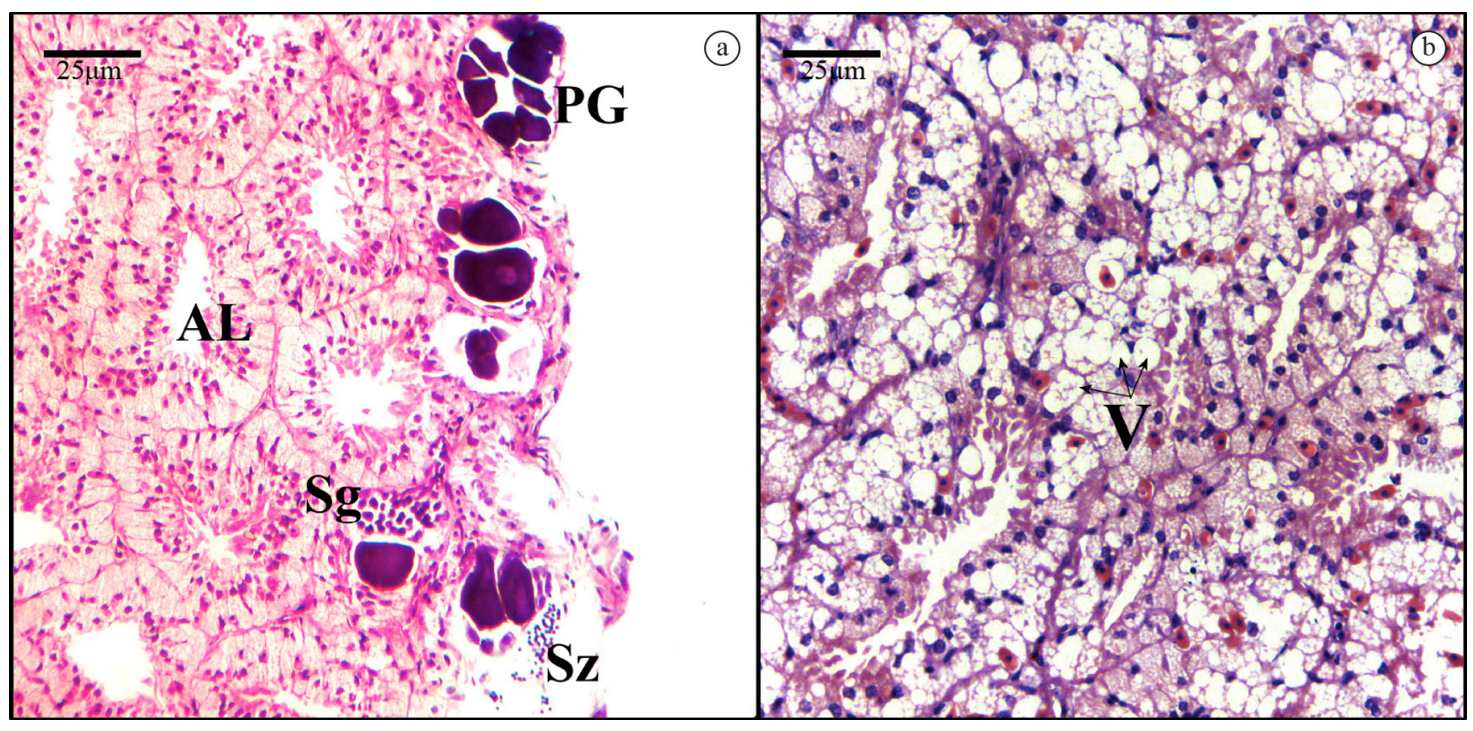

Figure 1. (a, b) Transverse section through the testicular gland region of a sperm-producing gonad of Gramma brasiliensis. $\mathrm{PG}$ - primary growth oocytes; $\mathrm{Sg}$ - spermatogonia; $\mathrm{Sz}$ - spermatozoa; $\mathrm{AL}$ - anastomosing lumina of testicular gland (TG) tubules; V- vacuoles. 


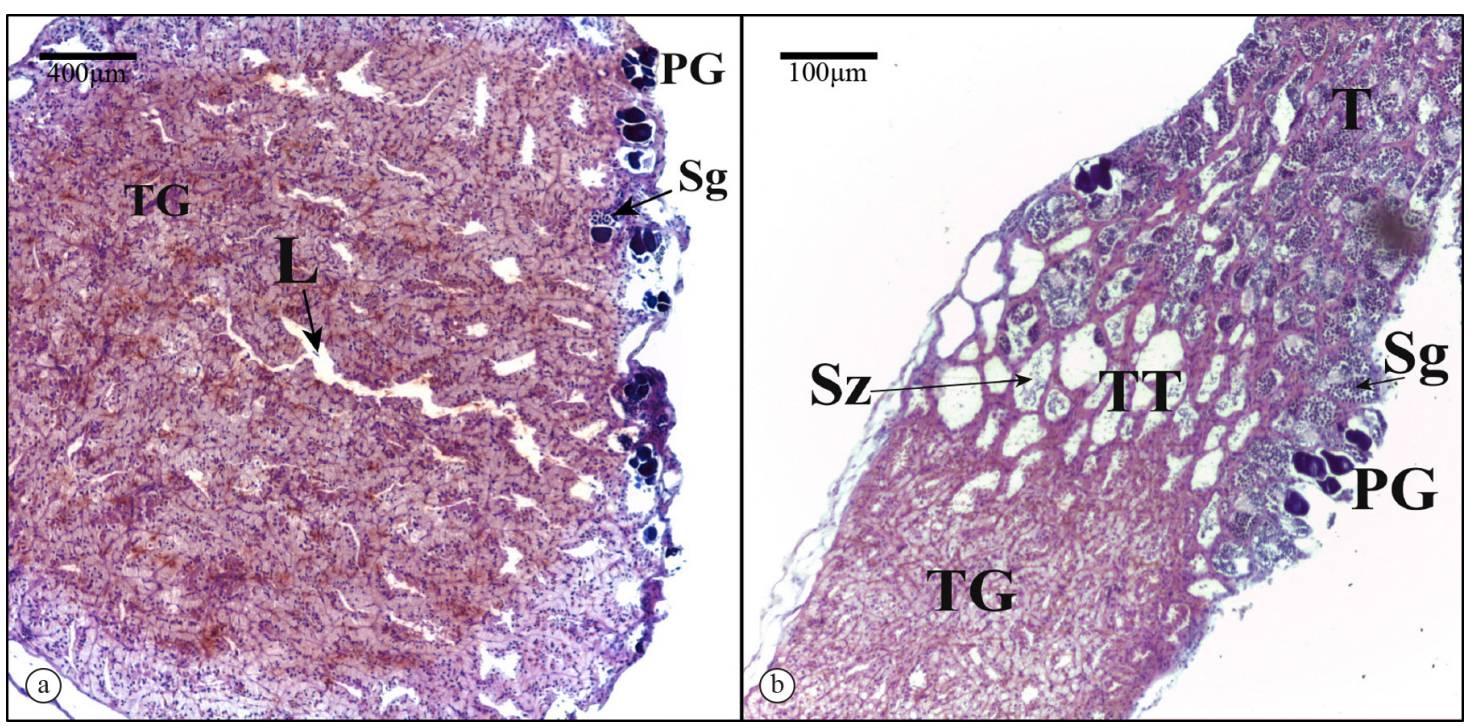

Figure 2. (a) Gonad transversal and (b) longitudinal sections through a sperm-producing Gramma brasiliensis. TG - testicular gland; T - spermatogenic region; TT - transitional region; L - lumen; PG - primary growth oocytes; Sg - spermatogonia; $\mathrm{Sz}$ - spermatozoa.

Table 1. Comparative table of the testicular gland tissue presence on each size class for female-active and male-active of Gramma brasiliensis collected between April 2011 and February 2012.

\begin{tabular}{ccccc}
\hline $\begin{array}{c}\text { Size class } \\
(\mathbf{m m})\end{array}$ & $\begin{array}{c}\text { Female-active } \\
(\mathbf{N}=\mathbf{3 8})\end{array}$ & $\begin{array}{c}\text { Presence of TG } \\
(\mathbf{\%})\end{array}$ & $\begin{array}{c}\text { Male-active } \\
(\mathbf{N}=\mathbf{4 2})\end{array}$ & $\begin{array}{c}\text { Presence of TG } \\
(\mathbf{\%})\end{array}$ \\
\hline $\mathbf{2 7 - 3 6}$ & 6 & 17 & 0 & 0 \\
$\mathbf{3 7 - 4 6}$ & 10 & 30 & 3 & 100 \\
$\mathbf{4 7 - 5 6}$ & 4 & 0 & 10 & 90 \\
$\mathbf{5 7 - 6 6}$ & 9 & 11 & 13 & 92 \\
$\mathbf{6 7 - 7 6}$ & 7 & 0 & 9 & 89 \\
$\mathbf{7 7 - 8 6}$ & 2 & 0 & 5 & 80 \\
$\mathbf{8 7 - 9 6}$ & 0 & 0 & 2 & 100 \\
\hline
\end{tabular}

In fish having a reproductively inactive gonad in which no mature germ cells were present, only oogonia and early stage (pre-vitellogenic) oocytes were present and TG tissue occupied approximately $50 \%$ of the gonad complex (Figure 3c).

In fish having a gonad predominated by spermatogenic tissue and the presence of spermatozoa, the TG made up more than half of the gonad complex, while spermatogenic tissue, which was proximal to the gonoduct and urogenital papilla also exhibited primary growth oocytes along the periphery of this region (Figure $3 \mathrm{~d}$ ). All the seven largest $(>77 \mathrm{~mm})$ male-active fish presented this pattern.

\section{Discussion}

The identification of the TG in both ovarian and testiform gonads in G. brasiliensis adds a species to the list of fish in which the TG is present and reopens the discussion about the possibility of hermaphroditic sexual pattern among Grammatid fishes. The presence of the TG in the vast majority (90\%) of male G. brasiliensis showed that the TG is a functional and essential organ in this species, with the histological features suggesting a secretory activity, and the presence of spermatozoa in the TG of the majority of active-males suggesting a storage function.

Brazilian Basslet have demersal eggs and does not exhibit sexual dimorphism, however, active-males tend to be larger than active-females in social groups. Therefore, it is likely that masculine hormones are linked to growth in response to social pressures, and the production of these hormones may occur in the TG. Furthermore the presence of some large active-females $(>70 \mathrm{~mm})$ can indicate that shift from ova to sperm-producing is not obligatory.

TG tissues identified in ovariform gonads of immature, developing, spawning capable and regressing G. brasiliensis fish indicate that the TG develops faster than the testicular tissue in sex change, adding strong evidence for hermaphroditism in this species. Sperm sinuses in $G$. loreto seemed to be identical to the TG tissue identified in G. brasiliensis and unlike was found in this study, Asoh and Shapiro (1997), did not identify any sign of sperm sinuses in the gonadal walls of $G$. loreto females, which was strong evidence for classifying the species as gonochoric. In females of some 


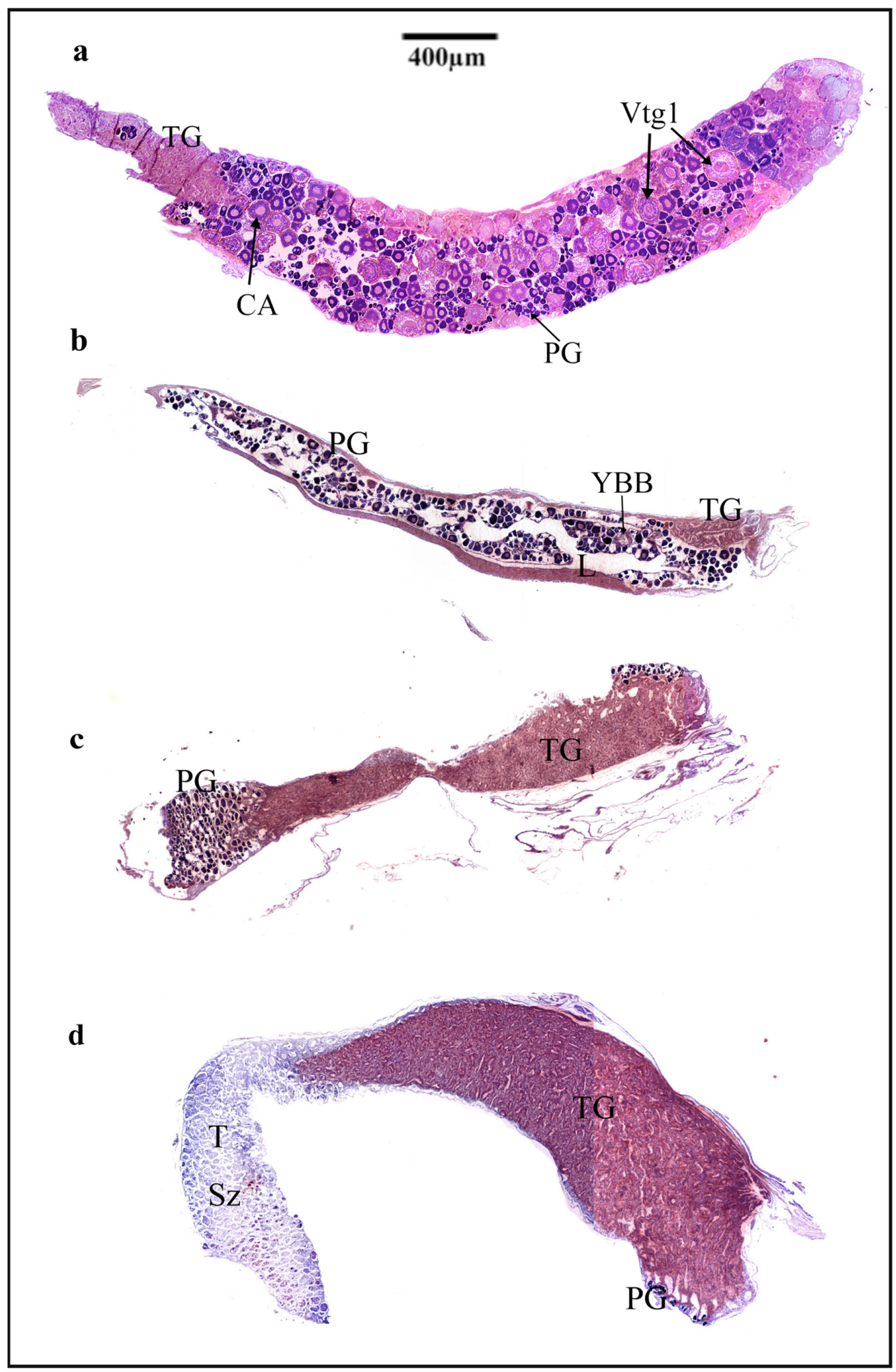

Figure 3. (a) Longitudinal section through an entire ova-producing gonad of a spawning capable I phase Gramma brasiliensis. (b) Longitudinal section through an entire ova-producing gonad of regenerating phase Gramma brasiliensis. (c) Longitudinal sections through entire sperm-producing gonad of developing phase G. brasiliensis. (d) Longitudinal sections through entire sperm-producing gonad of spawning capable I phase G. brasiliensis. PG - primary growth oocytes; CA - Cortical alveolar oocyte; Vtg1 - Primary Vitellogenesis; ML - medial lumen; TG - testicular gland; YBB - Yellow-brown Bodies; $\mathrm{Sz}$ - spermatozoa; $\mathrm{T}$ - spermatogenic region of gonad. 
protogynous gobies, a precursor to a testicular secretory organ develops during early gonadal differentiation. This precursor tissue mass remains quiescent during the female phase but grows and becomes functional during sex change (Cole, 1988, 1990; Cole and Shapiro, 1990).

Regan (1908) find in Priolepis cincta, mature ovaries containing testicular tissue and undeveloped pAGSs, while mature testes contain primary growth stage oocytes and fully developed pAGSs, which suggests a capacity for bi-directional sex change (Sunobe and Nakazono, 1999). Cole (2011) observed, in both Gobiodon okinawae Sawada, Arai and Abe 1972, and G. oculolineatus Wu 1979 , that accessory gonoduct structures were found in all individuals regardless of sexual state. This finding is the opposite pattern from that found in most gonochoric gobioid species, in which sperm duct-associated secretory structures have been described only in association with the male reproductive system. The presence of the TG in both juvenile and adult $G$. brasiliensis fish have ovariform gonads supports a hypothesis that the Brazilian Basslet may exhibit a protogynous sexual pattern.

Specific histological studies with controlled sex change-inducing experiments need to be performed to better understand testicular gland development and function in Gramma brasiliensis and other members of Grammatidae.

\section{Acknowledgements}

We are grateful to the Fundação de Amparo à Pesquisa do Espírito Santo for scholarship support. We are also grateful to Maik Da Hora, Johnatas Alves, Jamile Beninca, Leonardo Bueno, Instituto de Pesquisa em Aquicultura e Aquariologia, Neotropical Aquicultura Ornamental, Structural Biology Lab from Tropical Biodiversity Post-graduate Program of Universidade Federal do Espírito Santo for the field and laboratory support, and Projeto Meros do Brasil, sponsored by Petrobras - Programa Petrobras Ambiental.

\section{References}

ASOH, K. and SHAPIRO, D.Y., 1997. Bisexual juvenile gonad and gonochorism in the fairy basslet Gramma loreto. Copeia, vol. 1, no. 1, pp. 22-31. http://dx.doi.org/10.2307/1447836.

BEÇAK, W. and PAULETE, J., 1976. Técnicas de citologia e histologia. Rio de Janeiro: Livros Técnicos e Científicos. 230 p.

BÖHLKE, J.E. and RANDALL, J.E., 1963. The fishes of the Western Atlantic serranoid genus Gramma. Proceedings. Academy of Natural Sciences of Philadelphia, vol. 115, pp. 32-52.

BRASIL. Ministério do Meio Ambiente - MMA. Instituto Brasileiro do Meio Ambiente e dos Recursos Naturais Renováveis - IBAMA, 2004. Instrução Normativa $n^{\circ} 5$, de 21 de maio de 2004. Diário Oficial da União, Brasília, 28 may.

BROWN-PETERSON, N.J., WYANSKI, D.M., SABORIDOREY, F., MACEWICZ, B.J. and LOWERRE-BARBIERI, S.K., 2011. A standardized terminology for describing reproductive development in fishes. Marine and Coastal Fisheries, vol. 3, no. 1, pp. 52-70. http://dx.doi.org/10.1080/19425120.2011.555724.
COLE, K.S. and ROBERTSON, D.R., 1988. Protogyny in the Caribbean reef goby, Coryphopterus personatus: gonad ontogeny and social influences on sex-change. Bulletin of Marine Science, vol. 42 , pp. 317-333.

COLE, K.S. and SHAPIRO, D.Y., 1990. Gonad structure and hermaphroditism in the gobiid genus Coryphopterus (Teleostei: Gobiidae). Copeia, vol. 1990, no. 4, pp. 996-1003. http://dx.doi. org/10.2307/1446482.

COLE, K.S., 1988. Predicting the potential for sex change on the basis of ovarian structure in gobiid fishes. Copeia, vol. 1988, no. 4, pp. 1082-1086. http://dx.doi.org/10.2307/1445741

COLE, K.S., 1990. Patterns of gonad structure in hermaphroditic gobies. Environmental Biology of Fishes, vol. 28, no. 1-4, pp. 125-142. http://dx.doi.org/10.1007/BF00751032.

COLE, K.S., 2010. Gonad morphology in hermaphroditic gobies. In: K.S. COLE, ed. Reproduction and sexuality in marine fishes: patterns and processes. Berkeley: University of California Press, pp. 117-162.

COLE, K.S., 2011. Patterns of reproductive morphology in the genus Gobiodon (Teleostei: Gobiidae). Environmental Biology of Fishes, vol. 92, no. 3, pp. 323-335. http://dx.doi.org/10.1007/ s10641-011-9842-y.

COLOMBO, L.C. and BURIGHEL, P., 1974. Fine structure of the testicular gland of the black goby, Gobius jozo L. Cell and Tissue Research, vol. 154, no. 1, pp. 39-49. http://dx.doi.org/10.1007/ BF00221070. PMid:4442102.

COLOMBO, L.C., BELVEDERE, P. and PILATI, A., 1977. Biosynthesis of free and conjugated $5 \mathrm{~b}$-reduced androgens by the testis of the black goby, Gobius jozo L. Bollettino di Zoologia, vol. 44, no. 1-2, pp. 131-134. http://dx.doi.org/10.1080/11250007709430162.

CORSTEN-HULSMANS, C.J.F. and CORSTEN, A.J.A., 1974. Gramma loreto, een hermafrodite koraal vis van Curacao: oecologische aspecten en gevolgen van bevissing. Nijmegen: Katholieke Universiteit Nijmegen. vol. 92, 64 p. Report of Zoology Laboratory, Department of Dieroecologie.

DE MITCHESON, Y.S. and LIU, M., 2008. Functional hermaphroditism in teleosts. Fish and Fisheries, vol. 9, no. 1, pp. 1-43. http://dx.doi.org/10.1111/j.1467-2979.2007.00266.x.

EGGERT, B., 1931. Die Geschlechtsorgane der Gobiiformes und Blenniiformes. Zeitschrift fur Wissenschartliche Zoologie, vol. 139 , pp. 249-558.

FISHELSON, L., 1991. Comparative cytology and morphology of seminal vesicles in male gobiid fishes. Japanese Journal of Ichthyology, vol. 38, pp. 17-30.

FLOETER, S.R., ROCHA, L.A., ROBERTSON, D.R., JOYEUX, J.C., SMITH-VANIZ, W.F., WIRTZ, P., EDWARDS, A.J., BARREIROS, J.P., FERREIRA, C.E.L., GASPARINI, J.L., BRITO, A., FALCÓN, J.M., BOWEN, B.W. and BERNARDI, G., 2008. Atlantic reef fish biogeography and evolution. Journal of Biogeography, vol. 35, pp. 22-47.

GASPARINI, J.L., FLOETER, S.R., FERREIRA, C.E.L. and SAZIMA, I., 2005. Marine ornamental trade in Brazil. Biodiversity and Conservation, vol. 14, no. 12, pp. 2883-2899. http://dx.doi. org/10.1007/s10531-004-0222-1

GILL, A.C. and MOOI, R.D., 1993. Monophyly of the Grammatidae and of the Notograptidae, with evidence for their phylogenetic positions among perciforms. Bulletin of Marine Science, vol. 52, no. 1 , pp. 327-350. 
GILMORE, G.R., 1997. Lipogramma robinsi, a new Basslet from the Tropical Western Atlantic, with descriptive and distributional notes on L. Flavescens and L. Anabantoides (Perciformes: Grammatidae). Bulletin of Marine Science, vol. 60, no. 3, pp. 782-788.

GUTIÉRREZ, L.P. and BAÉZ-HIDALGO, M., 2002. Reprodución y alimentacíon del loreto Gramma loreto Poey, 1868 (Pisces, Grammidae), en la costa norte de la Habana, Cuba. Revista de Investigaciones Marinas, vol. 23, no. 3, pp. 195-201.

LAHNSTEINER, F., NUSSBAUMER, B. and PATZNER, R.A., 1993. Unusual testicular accessory organs, the testicular blind pouches of blennies (Teleostei, Blenniidae). Fine structure, (enzyme-) histochemistry and possible functions. Journal of Fish Biology, vol. 42, no. 2, pp. 227-241. http://dx.doi. org/10.1111/j.1095-8649.1993.tb00324.x.

MILLER, P.J., 1984. The tocology of gobiid fishes. In: G.M. POTTS and R.J. WOOTTEN, eds. Fish reproduction, strategies and tactics. London: Academic Press, pp. 119-153

MILLER, P.J., 1992. The sperm duct gland: a visceral synapomorphy for gobioid fishes. Copeia, vol. 1, no. 1, pp. 253-256. http://dx.doi. org/10.2307/1446565.

MOLINA, W.F., COSTA, G.W.W.F., BELLO-CIOFF, M. and BERTOLLO, L.A.C., 2012. Chromosomal differentiation and speciation in sister-species of Grammatidae (Perciformes) from the Western Atlantic. Helgoland Marine Research, vol. 66, no. 3, pp. 363-370. http://dx.doi.org/10.1007/s10152-011-0276-x.

MONTEIRO-NETO, C., CUNHA, F.E.A., NOTTINGHAM, M.C., ARAÚJO, M.E., ROSA, I.L., BARROS, G.M.L., 2003. Analysis of the marine ornamental fish trade at Ceará State, northeast Brazil. Biodiversity and Conservation, vol. 12, no. 6, pp. 1287-1295. http://dx.doi.org/10.1023/A:1023096023733.

RICHTARSKI, U. and PATZNER, R.A., 2000. Comparative morphology of male reproductive systems in Mediterranean blennies (Blenniidae). Journal of Fish Biology, vol. 56, no. 1, pp. 22-36. http://dx.doi.org/10.1111/j.1095-8649.2000.tb02084.x.

SAMPAIO, C.L.S. and NOTTINGHAM, M.C., 2007. Guia para identificação de peixes ornamentais volume I: espécies Marinhas. Brasília: Edições IBAMA. v. 100, 205 p.

SAZIMA, I., GASPARINI, J.L. and MOURA, R.L., 1998. Gramma brasiliensis, a new basslet from the western South Atlantic (Perciformes: Grammatidae). Aqua. Journal of Ichthyology and Aquatic Biology, vol. 3, no. 1, pp. 39-43.

STARCK II, W.A. and COLIN, P.L., 1978. Gramma linki: a new species of grammid fish from the tropical western Atlantic. Bulletin of Marine Science, vol. 28, pp. 146-152.

SUNOBE, T. and NAKAZONO, A., 1999. Mating system and hermaphroditism in the gobiid fish, Priolepis cincta, at Kagoshima, Japanese. Ichthyological Research, vol. 46, no. 1, pp. 103-105. http://dx.doi.org/10.1007/BF02674954.

VICTOR, B.C. and RANDALL, J.E., 2010. Gramma dejongi, a New Basslet (Perciformes: Grammatidae) from Cuba, a Sympatric Sibling Species of G. loreto. Zoological Studies (Taipei, Taiwan), vol. 49 , no. 6 , pp. 865-871.

YOUNG, R.T. and FOX, L., 1937. The seminal vesicles of the goby, with preliminary chemical and physiological studies of the vesicular fluid. Proceedings of the National Academy of Sciences of the United States of America, vol. 23, no. 8, pp. 461-467. http:// dx.doi.org/10.1073/pnas.23.8.461. PMid:16577795. 